\title{
BEZOEK VAN EEN HAARLEMMER AAN SURINAME EN CURAÇAO IN 1861 EN 1862
}

\author{
DOOR
}

\section{G. A, N. SCHELTEMA DE HEERE}

Het dagverhaal van den bezoeker is getrokken uit de reisbrieven van mijn oom Dirk Scheltema, die van zijn 15de tot zijn 21ste jaar zeevaarder ter koopvaardij was, daarna op Java in den handel ging, op zijn 26ste jaar benoemd werd tot Agent der Javasche Bank te Semarang, en in 1853 - oud 38 jaar - op zijn verzoek eervol uit dat ambt ontslagen werd, waarna hij voorgoed thuisvoer.

De aanteekeningen nopens de reis van Haarlem naar BritschGuyana zijn, als onbelangrijk voor Nederlandsch-Westindië, weggelaten.

Dinsdag 22 October I86I kwamen wij behouden te Georgetown aan de Demerary aan. Na ons goed te hebben gebracht aan boord van de Nederlandsche stoomboot „Vice-admiraal Rijk” 1) begaven wij ons aan wall. „Wij” beteekent hier de heer Hellmund 2), de heer Jules Garnier la Roche, een Fransch ambtenaar, die door het gouvernement van Guadeloupe gezonden was om de kolonie Cayenne te inspecteeren, en ik. Eerst bezorgde elk zijn zaken, wat bij mij bestond in de kennismaking met de heeren Rore Duff \& Co. $\left.{ }^{3}\right)$, kooplieden, bij wie ik een aanbeveling had. Vervolgens bracht ik den heer Thomas (hristiani 4 ), die bij zijn vrouw en 2

1) Genoemd naar den vice-admiraal Julius Constantijn Rijk (17871854), gouverneur-generaal van Suriname 1839-1842, minister van Marine. Zie D.W.I.G. 14de jrg. blz. 206 e.v.

2) Wilhelm Gottlob Frederik Helmund (1834-1910), eigenaar van zoutpannen op Bonaire en Aruba.

3) Rore Duff \& Co te Georgetown waren ,Merchants and storekeepers", tevens vice-consul van de Vereenigde Staten van Amerika en Lloyds agent.

4) Thomas Christiani, lid van den gemeenteraad, was ,,Merchant \& storekeeper". 
lieve kinderen recht gelukkig thuis was, een bezoek. Daarna ging ik naar het hotel Hamilton; ik vond er mijn reisgenooten en deed met hen een rit om Demerara te bezien, een plaats, welke reeds zeer waard is voor elkeen, die zoo op verscheidene stoombooten gebrek aan lucht, licht en gemak had gedurende een maand, doch in vergelijk met Nederlandsch-Indië er maar armoedig uitziet. Wij aten bij Hamilton vrij goed en maakten een niet ongenoeglijk avondbezoek bij den heer De Jongh in gezelschap van Israëlieten en Israëlitinnen.

Woensdag 23. Na het ontbijt ging ik naar boord en bestelde mijn passage bij kapitein Rustman, den gezagvoerder der genoemde boot. Hij stond mij zijn kamer voor de reis af en verzocht mij niet later dan op den middag, d.i. te 12 ure, aan boord te zijn. Ontbeten hebbende bij Hamilton en de rekening hebbende voldaan met een souverein, d.i. $f 12$ elk, begaven wij ons naar boord en vertrokken op het bepaalde uur, ons gelukkig voelende onder de Nederlandsche vlag hoewel wij van veel gemak verstoken waren. Maar wij naderden zoo langzamerhand het einde van het begin onzer reis.

Donderdag 24's ochtends te 6 ure lagen wij in den mond van de rivier Nickerie voor de stad Nieuw-Rotterdam $\left.{ }^{1}\right)$. Onder de hier aan boord komende passagiers waren de heer Tyndal de Veer ${ }^{2}$ ) en echtgenoote met 2 kinderen en 3 bedienden, die zich in de kajuit plantten en mijn nachtgoed en koffers verhuisden uit de kamer van den kapitein, terwijl een hunner koffers daarin geplaatst werd. Een half uur later vertelde ik den kapitein, dat het mij aangenaam zoude zijn, wanneer een ander rustverblijf voor mij in gereedheid gebracht kon worden. Onmiddellijk werd den hofmeester gelast de kapiteinskamer weder voor mij te bestemmen. Alles geschiedde, zonder dat zich boe of ba had laten hooren, zeer tot mijn genoegen.

1) Deze plaats aan de Nickerierivier werd door de zee verzwolgen. De Nickeriepunt werd in 1820 gesticht, in 1850 vergroot, en ontving toen den naam Nieuw-Rotterdam, in 1870 binnenwaarts verplaatst en voor de tweede maal in 1874 verplaatst. Het derde stadje, ver op de rivier Nickerie gelegen, werd Nieuw-Nickerie genoemd.

2) In 1862 wordt als eigenaar van de plantage Nursery in Nickerie vermeld de boedel Wed. E. Tyndall, boedel S. Tyndall, H. en Th. Tyndall, S. R. en J. de Veer Tyndall en Jos. Tyndall. Th. Tyndall, die 2de luitenant van de gewapende burgerwacht in het district Nickerie was en op de plantage Nursery woonde, was met H. Tyndall, J. de Veer

Tyndall, H. Blancke en P. C. Wesenhagen, administrateur in Suriname der plantage, waarvan $\mathrm{H}$. Tyndall directeur was. Andere Tyndall de Veer's of De Veer Tyndall's worden in Suriname niet vermeld. 
Vrijdag 25 des morgens ontwaakte ik in den mond der Suriname-rivier, nam van mijn medepassagiers afscheid, stapte op den Surinaamschen grond aan wal, en werd verwelkomd door den heer Soesman 1). Wij gingen samen naar zijn woning, waar ik een glas tamarinde-siroop dronk. Vervolgens begaf ik mij naar Lyons hotel. Daar zit ik nu in een afgeschoten hok te schrijven en ben er nog al slecht gelogeerd. Zoodra ik mij opgeknapt had, ging ik op bezoek naar den heer Brakke ${ }^{2}$ ) - die naar zijn plantage was -, den heer Gefken ${ }^{3}$ ) - wien ik een kaartje bracht van den heer Mr. Scherer en zeer beleefd ontvangen werd -, en den heer P. R. Planteau 4) - wien ik een open brief van diens zwager, den heer Van Heukelom 4), overhandigde en er ook een aangenaamste ontvangst had. Te 1 ure keerde ik naar mijn logement terug daar het mij wegens de warmte onmogelijk was verder te gaan. Van mijn neef Gajus Hajonides kreeg ik een kort bezoek, dat ik morgen hoop te beantwoorden.

1) Salomon Soesman, te Amsterdam geboren 28 November 1801, overleden te Coronie 3 April 1877, werd voor den handel opgeleid, en na in Londen werkzaam te zijn geweest, vertrok hij naar Suriname. Hij werd in 1866 lid van de Koloniale Staten, later ondervoorzitter en voorzitter. De handelszaak, welke hij oprichtte onder den naam van gebroeders Soesman, had een filiaal te Boston. Hij was eigenaar van de plantages Uit en Thuis en Mon Plaisir. De zaak verstrekte na de emancipatie eenige tonnen aan suikerplantages, maar leed groote verliezen en liquideerde.

2) Christiaan Daniel Brakke, geboren 5 Maart 1821, overleden 28 Februari 1885, was gehuwd met Henriette Carolina Flemming. Hij vertrok ongeveer 100 jaar geleden naar Suriname, was mede-eigenaar van de plantages Vlugt en Trouw (Boven-Cottica en Perica), Rust en Lust (Boven-Suriname), Dordrecht (Boven-Suriname), Sibano en Gelre (Commetewanekreek). Met zijn broer P. C. Brakke was hij directeur-administrateur van de plantage Johan en Margaretha (Beneden-Cottica). Zijn broer was directeur op de plantage Dordrecht.

3) Mr. J. W. Gefken (1807-1887) werd, na advocaat te 's Gravenhage geweest te zijn, rechterlijk ambtenaar in Nederland, en vertoefde van 1857-1867 als procureur-generaal in Suriname. N.N.B.W. IV, 639.

4) H.P. van Heukelom (1816-1878), directeur der Maatschappij tot exploitatie van staatsspoorwegen, later inspecteur der Nederlandsche staatsspoorwegen, huwde 1838 Charlotte Maria Planteau (1819-1869), geb. te Paramaribo, dochter van Jean Planteau en Clasina Theresia Thym. Van Heukelom en Vollenhoven waren administrateurs in Europa van de plantages La Rencontre en Maria Petronella, waarvan P. R. Planteau in Suriname administrateur was. Laatstgenoemde was ook administrateur van Johan en Margaretha, Vreeland, La Paix en De Maasstroom. 
Zaterdag 26. Gisteravond wandelde ik nog naar den heer Meindertshagen 1) - die naar de bovenlanden was -, zoodat ik nog tijd had een bezoek te brengen aan den heer Kramer, een koopman uit Oost-Friesland. Mijn logement is naar; Maandag hoop ik een beter vertrek te zullen hebben. Als ik 't raam uitzie, kijk ik op de binnenplaats, waar gister den ganschen dag een vrouw zat te wasschen met een pijpje in den mond. De voeding is hier naar omstandigheden vrij wel maar zonder rijst; pisang is de beste vrucht, welke ik hier tot nu toe vond: zij noemen die ,,bakoben”.

Zondag 27. Bij nadere overweging behoud ik mijn kamer maar, omdat ik er een zeer goede kast in gekregen heb tot berging van mijn goed. Gistermiddag was ik te dineeren en werd hartelijk ontvangen, maar om de leefwijze hier een weinig kennelijk te maken, zal ik de vreemde verzameling der hoofdschotels mededeelen, die trouwens alle van goeden smaak waren. Eerst soep, toen een pastij van zalm (versche) uit blik, daarna een fameus stuk zout vleesch, dat flankte met een schotel ragout van zout vleesch en kip. In den avond legde ik een bezoek af bij den gouverneur Van Lansberge 2), schoonvader van den heer Hellmund, en vond daar de mama met 3 getrouwde dochters, dames die zeer vloeiend Fransch en Spaansch spreken maar geen Hooghollandsch (Nederlandsch). Ik was dus zeer gelukkig, toen de gouverneur zich bepaalde om met den heer Hellmund en mij het gesprek in onze taal te vervolgen. Hedenmiddag ben ik daar te dineeren genoodigd. Van de stad zag ik nog weinig, want het is òf te donker ò te warm om te wandelen. De Joodsche kerk had ik gisteren gelegenheid om te zien. Het is een schoon lokaal, welgebouwd, zindelijk en welonderhouden; een gemeente van 600 menschen heeft er hare godsdienstige bijeenkomsten. Heden voor den middag was het niet

1) Mr. G. de Meinertshagen, lid van het gerechtshof, geboren 9 Maart 1808, overleden 24 Mei 1862.

2) R. F. van Lansberge (1804-1873) was achtereenvolgens ambtenaar bij de registratie in Nederland, gouvernements-ambtenaar in Curaçao, consulair ambtenaar in Zuid-Amerika, van 1856-1859 gouverneur van Curaçao, van 1859-1867 gouverneur van Suriname. Hij was gehuwd met Victoria Rodriguez (1806-1880), geboren te Neyva in Nieuw Grenada. Van zijn dochters was Charlotte Victoria Clemencia (1834-1864) gehuwd met W. G. F. Hellmund, Emilia Anna Elisabeth (1837-1905) met J. H. A. W. baron van Heerdt tot Eversberg (18291893), gouverneur van Curaçao (1880-1882) en van Suriname (18821885); Sophia Maria Victoria (1840-1894) trouwde G. W. C. Voorduin (1830-1910), die als luitenant ter zee de bekende platen van WestIndië vervaardigde. 
zoo warm als gisteren, maar ook toen, te 1 ure, hadden wij een flinke regenbui en heden in den namiddag zoo eenige stortbuien. De schoener, waarmee wij naar Curaçao moeten vertrekken, is nog niet aangekomen.

Maandag 28. Gister dineerde ik bij den gouverneur. Omdat het zooveel geregend had en nog regende, liet ik een rijtuig halen en reed daarmede naar het gouvernementsgebouw. Het rijtuig leek haast een lijkwagen, maar beantwoordde aan het doel. De 3 uren, welke ik aan het Paramaribo'sche hof doorbracht, waren aangename uren. Ik was de eenigste gast en de tafel, voor een gouverneur, eenvoudig maar lekker: dat is juist zoo 't zijn moet. De heer Van Lansberge is een zeer aangenaam en spraakzaam mensch. Leed was 't mij, met de dames niet wat meer te kunnen keuvelen. Toen het dessert op tafel stond, kwamen de kindertjes van 's gouverneurs 3 dochters binnen. Mijn medegasten in Lyons fameuze logement zijn de heer Theodoor Tydeman 1) uit Leiden met zijn vrouw en 2 kinderen. De heer Tydeman was vroeger zeeman, thans is hij landdrost (resident) van Coronie; hij is al sedert 3 maanden ziek en ook zijn vrouw is ziek; de kinderen en bedienden zijn nauwelijks hersteld. Nog logeeren hier - en met die gasten heb ik de eer de tafel te deelen - de goochelaar Taylor en zijn echtgenoote met hun compagnon, den zanger en gitaarspeler Mr. Pharlan. Zij vertrekken morgen naar Madeira om zoo de wereld door te goochelen, al reizende en trekkende. De vrouw verhaalde mij, dat zij al 3 jaren met haar man aan 't dwalen was, op 2 dagen na zoolang als zij getrouwd zijn, en dat zij aan boord altijd zeeziek is, maar dat het leven, dat zij leidt recht naar haar zin is.

Dinsdag 29 wandelde ik veel door de stad, bezocht den heer Roux $^{2}$ ) en den heer Planteau, welke laatste mij uitnoodigde morgenochtend om 6 uur een rit met hem om de stad te doen. Heden en gisteren had ik rijst en een lekkere ananas.

1) A. J. T. Tydeman, kwam in Januari 1857 in Suriname aan, ter beschikking gesteld van den gouverneur als assistent bij den procureur-generaal en provisioneel havenmeester. Hij bracht, op verzoek van den hoogleeraar W. H. de Vriese te Leiden, een plant van de getah pertsjah mede met de bedoeling die in Suriname aan te kweeken.

2) H. G. Roux, administrateur van St. Barbara, chef van het brandwezen en opperbrandmeester, thesaurier van den kerkeraad van de Hervormde gemeente, president van de commissie uit den kerkeraad tot toezicht over de weezen, voorzitter van de in 1849 opgerichte leesvereeniging ,, Keur van Letteroogst”. Hij was administrateur van 28 plantages in Suriname. 
Woensdag 3o. Om 5 uur in den morgen op, zoodat, toen de heer Planteau mij te 6 ure met rijtuig kwam halen, ik hem wachtte. Wij reden tot half 8 in 't westen der stad en zagen verscheidene boerderijen van menschen, die weinige jaren geleden als volkplanters 1) uitgekomen zijn en zich nu in de nabijheid van Paramaribo gevestigd hebben; zij vinden hun bestaan in den landbouw. $\mathrm{Na}$ een weinig gegeten te hebben begaf ik mij tot den heer Roux, wien ik ronduit vroeg, of hij mij niet in de gelegenheid kon stellen om de plantage Santa Barbara te bezichtigen. Met de meeste voorkomendheid bood hij mij aan, den Directeur der plantage te schrijven om een tentboot af te zenden, die mij als passagier stroomopwaarts zou voeren. De heer Roux beloofde mij tevens daar in de nabijheid ook nog gelegenheid te zullen geven om een plantage te zien. De heer Planteau zal mij mede een aanbevelingsbrief meegeven voor een plantage onder zijn opperbestuur, zoodat ik misschien reeds morgen de rivier opga, na bij den heer Planteau het middagmaal tusschen 1 en 2 uur gebruikt te hebben; maar misschien ook zal ik eerst overmorgen vertrekken. De heer Soesman beloofde mij later in de gelegenheid te zullen stellen op gelijke wijze een kijkje te gaan nemen op de plantage Adrichem. De gouverneur, waar ik hedenavond een bezoek bracht, gaf mij den wensch te kennen de landsplantage aan mij te laten zien, bijaldien ons vertrek daartoe genoeg vertraagde. Dus leerrijke dagen in 't verschiet. Hedenmiddag wandelde ik naar Tortone en Ma Retraite 2), 2 plaatsen in 't noorden der stad gelegen.

Donderdag $3 I$. Al vroeg was ik op de been en ging ook bij den heer Roux aan. Hij beloofde mij te zullen laten weten, wanneer de tentboot te mijner beschikking gekomen was. De heer Planteau ontving mij zeer aangenaam en wij aten te zamen zeer lekker. Des avonds maakte ik een bezoek bij Mr. Tyndal de Veer, die in het huis woont, waar vroeger zijn oom Jan Wesenhagen als eigenaar in woonde. Ik werd daar zeer wel ontvangen. Het is hier een geheel ander leven dan in de Oost; de kleederdracht der bedienden heeft lang niet dat eenvoudige en sierlijke der bedienden op Java, maar hier zijn de bedienden hoofd voor hoofd kostbaarder.

1) Bèdoeld zijn de Nederlandsche kolonisten van 1845, aanvankelijk in Saramacca gevestigd, waar een groot aantal door onvoldoende voorbereiding van hun vestiging stierf. Deze „Hollandsche boeren" vestigden zich later nabij de hoofdstad Paramaribo.

${ }_{2}^{2}$ Tortone moet zijn Tourtonne. Deze plantage was evenals Ma Retraite gelegen aan de Surinamerivier. 
Vrijdag I November I86I. Nu had ik gedacht heden de binnenlanden te bezoeken, maar jawel: de gelegenheid is nog niet gekomen. Dus heb ik mijn tijd zoo best mogelijk omgebracht met een brief te schrijven aan den heer J. Garnier la Roche. Maar nog is de schoener van Curaçao niet gekomen, en de tentboot van Sante Barbara is er evenmin.

Zaterdag 2. Ik voed nog altijd hoop heden naar genoemde plantage te zullen gaan en, hoewel de post eerst a.s. Maandag vertrekt, beëindig ik mijn briefwisseling maar heden.

Zondag 3. Mijne gezondheid laat niets te wenschen over. Het is hier het land van belofte, d.w.z. men schroomt niet te beloven, maar zeer traag komt men het na. Vermeende ik verleden Woensdag reeds naar de plantage Santa Barbara te gaan, die belofte is sedert van dag tot dag geprolongeerd - echter zonder voldoening der rente. Nog voed ik hoop derwaarts te gaan. Zoo jammer dat ik al dien tijd, welke ik zoo nuttig had kunnen besteden, genoegzaam zonder iets nuttigs uit te voeren doorbracht. Hedenmorgen bezocht ik de Luthersche kerk waar de Hervormde dominee Conradi $\left.{ }^{1}\right)$ preekte over Lucas 10, vers $23 \& 24$. De kerk, een niet groot maar luchtig en doelmatig gebouw, was wel bezet door burgers en ambtenaren, het garnizoen - ten minste een gedeelte matrozen en soldaten -, zelfs waren er vele vrouwen in inheemsche kleederdracht.

Maandag 4. De heer Klint 2), directeur der plantage Santa Barbara, bezocht mij hedenmorgen en stelde mij voor, met hem de reis aan te nemen te 3 ure, Hij had maar een 4-riemsboot en meende, ik moest maar wachten tot een 6-riemsboot afkwam om mij te halen: zulks paste beter voor mijn persoon. Ik gaf hem te kennen, dat mijn bijzonder verlangen is, hoe eer hoe beter te vertrekken, aangezien ik mijn tijd zoo aangenaam en zoo nuttig mogelijk wensch te besteden. Sedert gister weet ik, dat die heer hier is, en na 24 uren kwam hij eerst bij mij; ik acht het nog niet zeker, dat wij heden vertrekken, want te 12 ure wilde hij mij nog komen spreken en ik vat niet waarvoor zulks noodig is. Eindelijk zijn wij te 6 ure vertrokken in een 4-riems korjaal, bemand met 5 slaven, waarvan 1 de boot stuurde, waar wij heel gemakkelijk in zaten. Te 7 ure waren wij te Santa Barbara, waar wij ontvangen

1) Ds. C. Conradi (1807-1876) was van 1837 tot 1855 predikant bij de Vereenigde protestantsche gemeente op Curaçao en sedert $1857 \mathrm{bij}$ de Hervormde gemeente te Paramaribo. N.N.B.W. VII, 317.

2) J. P. C. Klint, directeur van de plantage St. Barbara. 
werden door den dokter Schreiber 1) en de 2 blanke officieren ${ }^{2}$ ) Liebeher en Kamen. Ook veel slaven en slavinnen, slaafjes en slavinnetjes kwamen ons begroeten. De slaaf Bienvenu, die zeer goed Nederlandsch spreekt, werd mij tot lijfdardanel teogevoegd gedurende mijn verblijf op de plantage; al spoedig ging hij een hangmat voor mij ophangen. Wij aten met smaak en gingen ter rust.

Dinsdag 5. In den morgen bezagen wij den molen en alles wat tot de suikerfabriek behoort, en deden een wandeling in de riettuinen. Des namiddags roeiden wij naar de suikerfabriek Sint Eustatius. De heer Brouw Muller ${ }^{3}$ ), de directeur, ontving ons zeer minzaam en bracht ons in de fabriek, die met stoomvermogen het riet vermaalde. De suikercultuur geschiedt hier geheel anders dan in Oost-Java; ook de bewerking en verpakking der suiker.

Woensdag 6 en Donderdag 7 bezagen wij het hospitaal, de kerk en de school. Vervolgens roeiden wij naar Accaribo, waar wij mede de fabriek bezagen. De kostgronden en de rietgronden van de onderneming Santa Barbara heb ik met den directeur Klint alle bezocht en nog de fabrieken Merveille, Maagdenburg en La Rencontre: wij verbeuzelden dus niet onzen tijd.

Vrijdag 8 ben ik alleen, in een 6-riemstentboot, bemand met 7 negers, teruggegaan. Te 6 ure was ik in 't logement, zeer voldaan over al wat ik gezien had.

Zaterdag 9 stond ik zeer verkwikt en uitgerust op, maar ik ben weder in mijne gedachten teleurgesteld, want ik meende heden naar een koffieplantage te zullen vertrekken en mag zulks nog maar niet in het verschiet zien. De mail kwam heden aan en bracht natuurlijk niets voor mij, want mijn brieven zullen op $\mathrm{Cu}$ raçao op mij wachten. In den avond ging ik visites maken en vond niemand thuis, dus troostte ik mij met een fiksche wandeling.

Zondag Io. Ik ging niet naar de kerk, omdat ik een weinig hoofdpijn had. Ik deed een wandeling, welke mij zeer verkwikte, en aan 't eind van welke ik de Protestantsche kerk bezocht, een zeer fraaie, zeer goed ingerichte koepelkerk, gevloerd met grafzerken van hier in den goeden, ouden tijd ontslapen manhafte,

1) G. C. F. Schreiber komt in 1837 voor als heelmeester in de divisie Boven-Suriname en Thorarica. Hij was gevestigd op St. Barbara.

2) Blanke officieren, kortweg geheeten blankofficieren, waren blanke opzichters op de plantages.

3) Brouw Muller moet zijn J. C. W. Braumuller, diaken van de Evang. Luthersche gemeente. 
eerzame en andere groote en kleine menschen. De gouverneur, dien ik hedenavond bezocht, gaf mij een pak Rotterdamsche couranten, pas uit Europa aangekomen; ik hoop er nu een weinig nieuws uit te lezen bij gebreken der op Curaçao mij wachtende familiebrieven.

Maandag II kreeg ik een gelegenheid om de plantage Dordrecht te bezoeken; hare mede-eigenaar is de heer C. D. Brakke, aan wien ik een aanbevelingsbrief had van de firma Wed ${ }^{\mathrm{e}}$. Van Hasselt \& $\mathrm{Co}^{1}$ ). Ik had dit schrijven nog bij mij gehouden, omdat de heer Brakke bij mijn komst in dit land zwaar ziek was. Nu is hij herstellende en logeert op Dordrecht, waar zijn broeder directeur is. Alleraangenaamst werd ik daar ontvangen. Na daar lekker gesoupeerd te hebben, voeren wij in de giek naar Paramaribo, waar wij te 10 ure aanlandden. Heerlijk was de vaart op de rivier bij prachtig weder en helderen maneschijn. Met nog 2 andere booten verlieten wij Dordrecht, maar onze 6 negers roeiden ons den anderen vooruit onder een wanluidend neusgezang waarmede de patroon, de neger die ons stuurde, instemde.

Dinsdag I2. Mevrouw Tydeman is bezig de kleederen voor de reis naar patria in orde te brengen.

Woensdag I3. Ik heb hier hetzelfde bier gevonden, dat ik thuis drink. Omdat het bier in mijn hotel duur en naar is, zoo heb ik een dozijn Lambier gekocht voor $f 5$, maar nu moet ik voor elke flesch, die opengetrokken wordt, 25 cent betalen onder de naam van kurkegeld, zoodat het bier dan kost $f 8$ het dozijn, wat dan nog goedkooper is dan het bier in 't hotel, en ik drink dan ook goed bier.

Donderdag 14. Gistermiddag was ik te dineeren bij den gouverneur, waar wij met ruim 30 personen aanzaten. De tafel zag er vroolijk uit; spijzen en dranken waren overvloedig en lekker; de bediening perfect. Ik maakte daar kennis met verscheidene heeren, waaronder de heer Slengarde 2), Administrateur van Fi-

1) De firma Weduwe Van Hasselt \& Co. was administrateur in Europa van de plantages Vossenburg en Johan en Margaretha.

2) E. J. Slengarde administrateur van Financien, wd. Inspecteur der Domeinen, van de Nijverheid en den Landbouw. Bij de instelling van dit laatstgenoemde ambt, bij resolutie van 13 December 1858 no. 1621 , werd de Koloniale ontvanger en betaalmeester A. Wildeboer als zoodanig benoemd met ingang van 1 Januari 1858. Met een tekort in kas vluchtte deze naar Barbados en verder naar Noord-Amerika. Slengarde, kapitein bij het bataljon Jagers no. 27, werd met diens functies belast. Hij was secretaris van de leesvereeniging ,,Keur van Letteroogst", ridder van de Nederlandsche Leeuw en eerelid van de Rotterdamsche diergaarde. 
nanciën, die mij toezegde een brief van kennismaking aan den directeur van den gouvernements-suikerstaat Catharina Sophia.

Vrijdag 15. Wel vertrekt eerst Woensdag de mail, maar ik dien heden mijn briefwisseling te sluiten omdat ik morgenochtend te 6 ure met de stoomboot vertrek naar evengenoemde plantage, van waar ik Maandag 18 denk terug te komen om dan Dinsdag 19 de reis naar Adrichem te ondernemen in een korjaal - niet kariool - met den heer Soesman, den administrateur. De creolenmoeder is op een plantage de matres van de bewaarschool, nog ouder en nog leelijker dan juffrouw Zoo-en-Zoo, die aan het hoofd eener beroemde bewaarschool staat. De creolenmoeder heeft onder haar opzicht al de kinderen van de plantage, die loopen kunnen en nog geen 8 jaar oud zijn: bijkans allen in puris naturalibus. Om de groote jongens van de grootere meisjes te kunnen onderscheiden, hebben de eersten een ouden stroohoed $o p$ het hoofd en de laatsten een bontgeruiten doek om het hoofd; die weelde is nochtans lang niet algemeen.

Donderdag 5 December I86I. Gister nam ik afscheid van de familie Tydeman, een heel verlies voor mij, want ik ging veel met die brave lieden om, maar voor hen is het goed, dat ze weg zijn want tot herstel van gezondheid hebben zij hoog noodig om eens wat koude lucht in te ademen en wat rust te genieten. 's Avonds ging ik op receptie bij den gouverneur. Ik was er in gezelschap met een 40-tal heeren en een 12-tal dames. Hoewel al wat receptie heet naar stijfheid riekt, moet ik zeggen, dat de avond mij geenszins lang viel. Ik had het geluk altijd met eenige heeren in onderhoudend gesprek te zijn en, doordat dan met deze, dan met gene heeren het gesprek plaats vond, zoo liep het discours over verschillende onderwerpen. Bij het afscheidnemen had ik met den gouverneur een kort maar aangenaam onderhoud, en toen ik beneden kwam vond ik den advocaat Van Emde 1), beladen met 2 ruiters, van wie ik eene mijn arm aanbood en zoo in nadere kennismaking kwam met deze familie, welke ik bereids door en bij de familie Tydeman had leeren kennen.

Vrijdag 6. Des avonds bracht ik een bezoek bij den heer Slengarde, die mij uitnoodigde morgen op het piket van politie een vergadering bij te wonen van geneeskundigen ter schouwing van

1) Advocaat Van Emde moet zijn Van Emden en kan zijn: mr. A. van Emden, mr. E. A. van Emden, gouvernements-secretaris en ambtenaar van den Burg. Stand, de landspraktizijn mr. A. J. van Emden of de president van het college van Kleine Zaken Egbert van Emden. 
melaatschen. Hier is de plaats, waarvan door den philanthroop Van Hoevel 1) een afbeeldsel gegeven is in zijn veelbesproken werk over de slavernij in deze gewesten.

Zaterdag 7. Ik ontvang daar juist eene uitnoodiging om een paar dagen te komen doorbrengen bij den heer E. F. L. Mollinger ${ }^{2}$ ) op zijn plantage Voorburg, welke ik aannam, en de scheepsgelegenheid eener tentkorjaal wacht. Recht onaangenaam is het, dat ik niet nader kan komen tot het doel mijner reis, maar mijn verblijf hier is allerbelangrijkst.

Zondag 8. Gister zat ik den ganschen dag te wachten op de korjaal van Voorburg tot 's avonds 7 uur, toen ik uitging en o.a. een bezoek bracht bij den heer E. J. Wesenhagen ${ }^{3}$ ), hoofdcommies ter gouvernements-secretarie, tijdelijk belast met de betrekking van gouvernements secretaris, broeder van wijlen Jan Christiaan Palthe Wesenhagen ${ }^{3}$ ). Hedenochtend onder het ontbijt kwam de bootsman van Voorburg en nu reis ik over een uur af, zegge te 9 ure. De plantage Voorburg is de eerste suikerstaat in de rivier Suriname, nadat men 't fort Amsterdam gepasseerd is, in concessie, groot 14011/2. akker en bevolkt met een macht van 194 slaven; de eigenaar is voornoemde heer Mollinger, die gewoonlijk met zijn gezin daar woont. Zijne echtgenoote en kinderen zijn nu in de stad. Er wordt gewerkt met een stoommachine van 8 paardekracht, vervaardigd aan de fabriek van Paul van Vlissingen 4) in 't jaar 1838; het werktuig is echter oud. Ik ben hier uitnemend gelogeerd.

Maandag 9 roeiden wij naar de suikerplantage Kroonenburg in de Cottica, eigendom van den heer Insinger s) te Amsterdam on-

1) W. R. baron van Hoëvell (1812-1879), predikant in NederlandschIndiē, later lid der Tweede kamer, ijveraar voor de afschaffing der slavernij, schreef in 1854 Slaven en vrijen onder de Nederlandsche wet.

2) E. F. C. Mollinger, eigenaar van de plantage Voorburg. Het administratiekantoor Mollinger en Janssen Eyken Sluyters beheerde talrijke plantages in Suriname (12 stuks). De heer Mollinger alleen was administrateur van 5 plantages.

3) J. E. Wesenhagen, hoofdcommies ter gouvernements-secretarie, diaken van de Hervormde gemeente van Paramaribo, secretaris van den Pupillairen raad en plv.lid van het college van commissarissen van het departement der onbeheerde boedels. Hij was een broer van Jan Christiaan Palthe Wesenhagen, fd. president van het gerechtshof en van het militair gerechtshof (geb. 23 Juni 1810, overleden 8 Juli 1859).

4) Paul van Vlissingen (1797-1876), oprichter in 1827 van een fabriek, oorspronkelijk tot herstelling van schepen, op Oostenburg te Amsterdam. N.N.B.W. VII, 1273.

s) De firma Insinger \& Co. was eigenares van de plantages Kroo- 
der de administratie van de heeren Mollinger en Eyken Sluyters 1) en directie van den heer Sluyters. De slavenmachten van de plantages Anna Catharina en Zeelust zijn hier bijeengebracht, zoodat de macht 900 koppen bedraagt. De negerhuizen vormen hier 2 dorpen, van welke het eene Zeelust, het andere Anna Catharina genoemd wordt. Alles wat tot de fabriek en comfort bestemd is, werd door ons bezocht. Alles, behalve de negerhutten en het hospitaal, die geheel nieuw van bouw zijn, zal nieuw opgericht worden, waarmede de vereischte voortgang plaats vindt; met het oude machinewerk had de maling juist heden een aanvang genomen. $\mathrm{Na}$ hier alles bezichtigd te hebben, wandelden de heer Mollinger en ik naar den buurman Jackson ${ }^{2}$ ), directeur der plantage Brouwerslust, waar wij het ontbijt gebruikten en vervolgens terugroeiden naar Voorburg. Onderweg stapten wij nog uit bij den divisie-dokter Katel, waar wij thee dronken en verscheidene daguerreotypes zagen, genomen door den heer Seyler; geen er van droeg echter het bewijs, dat die kunstenaar meester in zijn vak is. Op Voorburg teruggekomen, nam ik onder dankbetuiging afscheid van mijn beleefden gastheer en vertrok naar Paramaribo waar ik te 8 ure des avonds aankwam, vernemende dat de schoener ,Anna" eindelijk gekomen was.

Dinsdag Io. Met den heer Hellmund bezocht ik den schoener. Wij vernamen, dat nu de kans bestaat om over 9 of 10 Surinaamsche dagen te vertrekken. Nog bezocht ik den heer Slengarde, die geen woord sprak van ons plan tot andermalig bezoek der plantage Catharina Sophia. Toen ik gister op Voorburg aankwam,

nenburg (Beneden-Commewijne), Wederzorg (Beneden-Commewijne), Barbados (Saramacca) en Anna Catharina (Mattapica).

1) Tj. Janssen Eyken Sluyters, heemraad van Boven- en BenedenCommewijne, permanent lid van den Kolonialen raad, was met den heer E. F. L. Mollinger administrateur van de plantage Kroonenburg, en mede-eigenaar, met zijn broer mr. J. M. J., van de plantage Geyersvlijt, correspondent en eerelid van het Koninklijk Zoölogisch Genootschap „Natura Artis Magistra” te Amsterdam. In zijn district was de houtgrond Bergendal gelegen, waarop een opstand onder de negers was uitgebroken. De gouverneur, wien het bekend was, dat de K.O.B. A. Wildeboer goeden invloed op de negerbevolking kon uitoefenen, zond dezen naar Bergendal om de negers tot orde en rust te manen. Janssen Eyken Sluyters vatte zulks als een bewijs van wantrouwen op en nam zijn ontslag als heemraad, dat hem bij resolutie van 24 Juni 1856 eervol gegeven werd. Hij was administrateur van 12 plantages.

2) J. H. Jackson, gehuwd met Sara Anna Heilbron, directeur van plantage Brouwerslust aan de Commewijne, 2de luitenant van de gewapende burgermacht in Beneden-Cottica. 
werd er juist een visch gevangen van de soort, die men hier ,,geelbagger" 1) noemt; hij was zoo groot als de beste kabeljauw, welke ik nog gezien heb; die visch was lekker; men wint er de vischlijm uit.

Woensdag II. Gisteravond wandelde ik naar den heer A. M. Koster, die mij voorstelde met hem een bezoek te brengen op Geyersvlijt bij den heer Tjerk Jansen Eyken Sluyters 2), eigenaar dier plantage, met zijn broeder. De heer en mevrouw Eyken Sluyters wenschten mij tot heden te houden, en ik liet mij hun gastvrije aanbieding welgevallen, maar in het ruime, luchtige vertrek rustte ik niet zoo aangenaam als op Voorburg; wellicht omdat ik gisteravond een glas rooden wijn dronk. Hedenochtend reden wij met rijtuig door 't bosch naar den kostgrond (de bananen- of pisangtuinen) en bezochten de savanne (het weiland), waar ongeveer 100 runderen graasden. Vervolgens bezagen wij het kabinet van opgezette viervoetige dieren, vogels en insecten, alle in deze kolonie gevangen en bereid door den hier woonachtigen Duitscher Wakker. Dit kabinet van den heer Sluyters is een rijke verzameling; zijn verzameling levend gedierte is niet zoo rijk, evenwel voorzien van schoone exemplaren.

Donderdag I2. Gistermiddag kreeg ik een uitnoodiging van den heer Brakke om heden een uitstapje met hem te gaan doen, waartoe ik gaarne instemde. Van den gezagvoerder der schoener „Anna" vernam ik, dat er Europeesche brieven voor mij op $\mathrm{Cu}$ raçao liggen.

Maandag 16 . Gisteren kwam ik in den middag thuis na met den heer D. Brakke de plantage Dordrecht, Johan \& Margaretha,

1) Geelbagger, Sciadeichthys luniscutis, is een zeevisch.

1) Mr. J. M. J. Janssen Eyken Sluyters, een broer van den voorgaande, was medeêigenaar van de plantage Geyersvlijt, ouderling van de Evangelisch Luthersche gemeente, lid van de commissie van onderwijs en eerelid van de Rotterdamsche diergaarde. Het gelukte gouverneur Van Lansberge hem in 1864 te bewegen zijn verzameling van voorwerpen van natuurlijke historie aan de kolonie te schenken en niet naar Nederland te zenden (zie Gouv. Advertentieblad van 16 Februari 1865). Deze verzameling werd tot opzeggings toe in bruikleen gegeven aan het Genootschap tot bevordering van kennis tot 1875 . $\mathrm{Zij}$ werd de grondslag van het Koloniaal museum te Paramaribo, dat tot 1908 heeft bestaan en toen bij resolutie van den gouverneur van 16 Mei no. 4439 werd opgeheven in verband met den verwaarloosden toestand, waarin het zich bevond, en met de uitbreiding van de koloniale boekerij, welke zich in hetzelfde gebouw bevond. De aanwezige voorwerpen werden aan openbare en particuliere onderwijsinrichtingen te Paramaribo geschonken. 
Visscherszorg, Maasstroom, Jagtlust en Geyersvlijt 1) bezocht te hebben. Op de laatste plantage zag ik in het bosch, onder andere groote boomen, verscheidene van de soort die men hier „Bortrie” of ook wel „Bolletrie” ${ }^{2}$ ) noemt, welke de getahpertjah voortbrengt en - naar mij verhaald wordt - een drinkbare melk geeft. Op de plantage Johan \& Margaretha zag ik 2 flinke, sterke negers, die weigerden te arbeiden, waarom de administrateur gelastte hen op te sluiten en zonder een woord te kikken of het minste verzet lieten de oproerigen zich ongebonden opsluiten. Hedenochtend bezocht ik de schoener „Anna" en ook de schoener „Arno"; ik ben nog niet bepaald met welk vaartuig ik de reis zal doen; beide zijn lieve scheepjes maar bieden al even weinig gemakken. Alle plantages hebben Europeesche maar ook neger-namen. Zoo heet Geyersvlijt in het Negerengelsch ,Jan Koiri", omdat een vorige eigenaar, die Jan heette, alle dagen naar de stad wandelde en dan voegden de negers elkander toe: ,Jan kuiert (wandelt), wij hebben vrijaf", waarvan de negernaam der plantage gekomen is.

Dinsdag 17 . Terwijl de muskieten en mompieren ${ }^{3}$ ) - deze laatste zijn mede een soort van bloedgulzige, zeer lastige, kleine maar venijnige dieren - mij bijten en azen op het bloed van mijn rechter zoowel als van mijn linkervoet, kan ik melden besloten te zijn met de schoener „Anna” de reis naar Curaçao aan te nemen, maar eerst ga ik daarmede naar de rivier Saramacca om rum van de plantage Catharina Sophia af te halen. Mijn besluit om met de "Anna" de reis te ondernemen vindt misschien wel veel oorzaak in den naam van de schoener (de moeder en een der dochters des schrijvers heetten zoo) doch de schoener „Arno" heeft tot gezaghebber Pieterson en ik ben bang dat die vriend mij te veel zal

1) De plantage ontving haar naam van den eersten aanlegger en eigenaar Johan Christiaan Geyer, raad van justitie, geboren te Groszenindestadt in het vorstendom Eisenach 19 Juli 1751, overleden 5 Juni 1823 na een verblijf van 55 jaren in Suriname, waarheen hij als militair was gegaan.

2) A. Wildeboer, koloniaal ontvanger en betaalmeester, ontdekte in 1856, op den grond Bergendal zijnde, dat het sap van de bolletree, door insnijding verkregen, veel overeenkomst met guttapercha had. Zijn huisdokter Jan Anthony Muller Jzn, een zwager van jhr. Isaac Johs. Rammelman Elsevier, gouverneur van Curaçao (1849-1854), toen in Nederland vertoevende, eigende zich deze ontdekking wederrechtelijk toe, tengevolge waarvan de hoogleeraren Bleekrode, De Vriese en Blume te goeder trouw deze stof den naam van Sapota Mulleri Bl. hebben gegeven. Dr. Muller had nl. takken van dezen boom aan zijn zwager gezonden.

3) Kriebelmuggetjes (Diptera). 
plagen met verschillende geslachten van ongedierten als daarvan eenige exemplaren in deze gewesten gevonden worden.

Woensdag I8. Overmorgen gaat de mail, maar heden reeds moet ik mijn briefwisseling sluiten omdat ik morgenochtend vroeg met de schoener „Anna” naar de plantage Catharina Sophia denk te vertrekken. Eindelijk begint de horizont van ons vertrek, hoewel nog steeds in nevelen gehuld, zichtbaar te worden en ik hoop toch nog deze maand deze prachtige, vruchtbare oorden te verlaten voor Curaçao, waar ik verneem de natuur niet zoo rijk aan plantengroei is als hier, maar waar de menschen toch stellig even gastvrij zijn als hier te Paramaribo. Wel moet men hier veel geduld hebben, ten minste ik; immers had ik mij, van Haarlem uitgaande, voorgesteld nu bereids verscheidene weken op Curaçao te zijn. Van Saramacca teruggekomen, zal er met Paramaribosche haast gewerkt worden voor ons vertrek naar Curaçao: ik zal maar vast weder mijn geduld oefenen.

Donderdag I9. Gisteravond vernam ik dat de heer Hellmund niet mee zou gaan naar Saramacca, en zoo besloot ik maar hier te blijven. De hoop bestaat nu om de volgende week naar Curaçao te zullen vertrekken. Hedenmorgen maakte ik de opmerking, dat de kleine negertjes nooit op de broek krijgen.

Vrijdag 20 en Zaterdag 2I. De schoener "Anna" is nu naar de rivier Saramacca. Aanstaanden Maandag is het reeds 3 maanden, dat ik van huis ging, en nog ben ik niet op de plaats mijner bestemming.

Zondag 22. Gistermiddag en -avond regende het verschrikkelijk; er was aan geen uitgaan te denken. De muskieten plaagden mij den laatsten nacht onophoudelijk. Toch ontwaakte ik vroeg en aanschouwde den heerlijken ochtendstond. De straten zijn, hoewel vochtig, toch zeer begaanbaar en zoo deed ik in de vroegte een zeer aangename wandeling. Daarna werd het te warm. De heer Coster, die veel zaken omtrent houtwaren heeft met de boschnegers ${ }^{1}$ ), bracht mij een bezoek en heeft mij weder veel belangrijks van die natuurmenschen verhaald.

Maandag 23. Ik heb nog niet verteld, dat ik hier geen vuilniskarman gezien heb; men zou dus denken, dat vooral de erven, maar ook de straten, vuil zijn. De erven, ja: ten minste die van de 2 fameuze hotels. De straten worden schoongehouden door een menigte vogels uit het gierengeslacht, in het Negerengelsch

1) De zaagmolen van den heer Coster op de Combé bestond nog een dertigtal jaren geleden. 
„,tiengie fowloe" en in het Nederlandsch ,,stink-" of ,,aasvogels" genoemd. Zij voeden zich met velerhande soort van vuiligheid, waarom een groote boete gesteld is op het dooden van zoodanige vogels: mij is verhaald 600 gulden; of het waar is weet ik niet. Om een proefje te geven van de voortvarendheid van den kapitein der schoener ,Anna” zal ik herinneren, dat genoemd vaartuig den 9den dezer hier aankwam, haar lading loste met alle traagheid, en eindelijk met genoegzamen last in zou vertrekken op Woensdag 18 dezer des morgens te 6 ure, maar hier verzeilde Donderdagavond te 9 ure en toen bij 't fort Amsterdam - hier een uur roeiens vandaan - ankerde om in wezenlijkheid eerst des Vrijdagsmorgens te vertrekken, dus 11 dagen, waar 3 etmalen tijds genoegzaam waren geweest. Had die schipper zijn tijd nuttig besteed, dan waren wij reeds op Curaçao geweest.

Dinsdag 24. Nog is de schoener niet terug, en al komt die heden, vrees ik toch, dat wij morgen en overmorgen, de Kerstdagen, zullen moeten overliggen. Somtijds, als ik om dien tragen schipper denk, begint het bloed mij te koken.

Woensdag 25. Gisternamiddag bewoog zich alles naar de Hernhutterkerk, die te 7 ure een aanvang zoude nemen. Elk ging dus veel vroeger derwaarts in de vreeze van geen plaats te zullen krijgen. De stad wemelde alzoo van zwarte, gele, bruine, bronzen, vale en allerhande soort gekleurde vrouwen en meisjes, geheel in 't wit gekleed, maar gelaat en voeten ongedekt. Als men de ruime straten tusschen 5 en 6 uur doorzag, was het alsof de graven ontruimd waren. Nieuwsgierigheid dreef ook mij naar die kerk. Zij was vol, terwijl tal van vrouwen en meisjes op den drempel verbleven, omdat daarbinnen geen plaats was, en buiten onder de ramen stonden de hoorders in den regen. Inmiddels was de toeloop nog groot. Wel had ik in de kerk veel hoofden en brandende kaarsen gezien, ook den galm van des voorgangers stem gehoord, maar toch verwijderde ik mij onbevredigd, en maakte later een bezoek bij Zijne Excellentie Van Lansberge, waar ik als altijd hartelijk ontvangen werd. De schoener is nog niet van Saramacca terug.

Zaterdag 28. Gister en eergister gevoelde ik geen schrijflust. Ik ben verdrietig, dat er geen vooruitgang is in de mij opgedragen zaak, maar ik vind geen troost, want altijd krijg ik ten antwoord: ,Mijnheer is in Suriname en hier gaat alles langzaam, maar 't komt terecht". Ellendig beginsel.

Maandag I3 Januari 1862. Wel, dat is een lange rek in 't journaal. Ik ben zoo ziek geweest, dat ik niet kon staan op de 
beenen, niet kon spreken en niet kon zien. Deze week nog hoop ik naar Curaçao te vertrekken in de schoener „,Transit”, kapitein A. Th. Neuman. Hoewel zwak, ben ik onder de herstellenden. Ik heb het hardewaal gehad. Doctor Juda ${ }^{1}$ ) heeft mij onder zijn goede behandeling en voegde $\mathrm{mij}$ al dadelijk een gespierde negerin toe, die mij als een ware pleegzuster, gedurende mijn gansche ziekte verzorgd heeft, dag en nacht. Mevrouw Van Lansberge zond mij wat de dokter uit de keuken voorschreef en mevrouw Mauritz Ganderheyden 2) arrowrootpap en geleien, die de dokter gunstig keurde; nu begin ik een weinig te eten en een glaasje wijn te drinken. Ik verlang hard naar Curaçao, want daar liggen al mijn brieven uit patria; tot heden hoorde ik niets van daar. Mijne ziekte voert den naam van ,,geelzucht".

Maandag 20 vertrok de laatste mail en ik verzond daarmede mijne brieven, die ik den 13den t.v. afsloot in de gedachte toen spoedig van Paramaribo te zullen vertrekken. Nu is mijn reisplan weder bepaald op overmorgen in de schoener "Transit", wanneer ik juist drie maanden zal geweest zijn in dit land van belofte en teleurstelling maar ook van warme vriendschap - in plaats van 8 dagen, zooals het plan was bij de afreize uit patria. Ik heb hier veel geleden, maar nu schijnt de zon weder. Tevreden zal ik zijn de rivier Suriname uit te wezen, want in de bovenlanden beginnen de negerslaven onwillig te worden, zoodat het gouvernement zich verplicht vond naar die streek gister en eergister af te zenden de oorlogsschoener ,Schorpioen", commandant Star Nauta, en de stoomboot „Nickerie” met 100 soldaten en den gouvernements-commissaris Donker Curtius, procureur-generaal in deze kolonie ${ }^{3}$ ).

Vrijdag 24. Ik begin wezenlijk te gelooven, dat ik morgen hier vandaan vertrekken zal. Ik begin in krachten toe te nemen en ook mijn gezicht wordt een weinig helderder.

Zaterdag 25 begaf ik mij tusschen 8 en 9 ure aan boord der "Transit", een schoener van $221 / 2$ gemeten scheepslasten, waarmede ik te 3 ure des namiddags de reede van Suriname verliet. De gouverneur R. F. van Lansberge, van wien ik nog eenige regelen tot afscheid ontving, had laten seinen om ons ongemoeid

1) J. J. Juda, M. C. et O. (Utrecht 1848).

2) Mr. Maurits Ganderheyden was president van het gerechtshof.

3) Bedoeld zal zijn W. Donker Curtius, gouvernements-commissaris, of Mr. B. Donker Curtius, lid van het gerechtshof en waarnemend advocaat-fiscaal, president van de kerkelijke commissie. Procureurgeneraal was mr. Gefken. 
het fort Amsterdam te laten passeeren en zoo kwamen wij zonder oponthoud, door wind en stroom geholpen, des avonds te kwart voor 6 in zee, onzen koers toen noordwest stellende.

Maandag 27 bevonden onze middagbreedte $9^{\circ} 7^{\prime} \mathrm{N}$ en bleven noordwest sturen, met welken koers wij des morgens van den 28sten te 6 ure het eiland Tabago in 't zicht kregen aan stuurboord, en weldra aan bakboord Trinidad. Veranderden onzen koers naar aanleiding der afgelegde verheid (afstand) tot west.

Woensdag 29. Bij het aanbreken van den dag zie ik "Siete Testugos" (Zeven Getuigen) aan stuurboord, dwars van ons. Sturen steeds west. Vangen te half 7 een koningsvisch, waarvan ik bij 't ontbijt met smaak een stukje proefde. De gezondheid gaat vooruit. In den voormiddag zagen Soley, een op zichzelf staande klip in 't noorden, terwijl wij ,Los siete Frailes" (De zeven Monniken) en „Marguerite" in 't zuiden hadden. Stelden onzen koers noordwest-ten-westen en bereikten zoo „Los siete Hermanos” (De zeven broeders), waar wij te half 4 ure tusschendoor zeilden, toen onzen koers west-ten-zuiden stelden en weldra Blanquilla westnoord-west van ons zagen: hier hebben de Venezuelanen een groote veeteelt.

Donderdag 30 zag ik des morgens te half 7 het eiland Orchilla in 't noorden. Sturen west-ten-noorden. Zagen te 10 ure voormiddag de eilanden Roques aan stuurboord. Deze eilanden, zeer laag en begroeid met amandelboomen en veevoeder, worden veel door visschers bezocht, die als herkenningsteeken een groen schijnsel aan de wolken waarnemen, hetgeen veroorzaakt wordt door de reflexie van een groen binnenwater, dat zich tusschen die klippen bevindt. Achtermiddags, 's avonds en 's nachts stormachtig met veel regen, in den ochtend echter helder.

Vrijdag $3 I$. In den voormiddag wederom buiige lucht. Hadden 's nachts gestuurd om vrij van de Avis-eilanden te blijven en wisselden onzen koers verder naar gelegenheid van wind en weder. Des morgens te 8 ure zagen het eiland Curaçao (De gebraden Priester) en liepen te half 12 de haven binnen. De heer Hellmund kwam aan boord, zoodra wij de haven binnen waren en nam mij met zich naar huis, waar ik mijn intrek nam in een luchtig vertrek. Ik begon met in de ruime woning wat op en neer te wandelen, daar ik de immer bewegende „Transit” geene beweging van dien aard gekend had. Weldra ontving ik alle brieven-pakketten van Amsterdam; de lezing van dien schat hield mij, met mijn zwak gezicht, 2 uren bezig waarna ik naar rust verlangde.

Zaterdag I Februari I862. Aan 't eind van een rustigen nacht 
ontwaakte ik verkwikt en ik trachtte een weinig met de plaats en gemeente in kennis te komen. Ik verzuimde van Paramaribo te schrijven, dat de nachtwacht daar roept: „Bewaar je vier en ligt". Nu ben ik weer beter maar nog zwak.

Zondag 2. Heden zou van Paramaribo naar Nederland vertrekken de weledelgestrenge heer J. van Lansberge ${ }^{1}$ ), officier bij de Nederlandsch-indische Jagers, zoon van den gouverneur. Hij heeft mij beloofd mijn huis te bezoeken, als hij in Haarlem komt, en als dat gebeurt, moet hij goed onthaald worden. Met zijn vader en moeder heeft hij mij gedurende mijne ziekte te Paramaribo buitengewoon veel beleefdheden bewezen.

Maandag 3. Hedenmorgen heb ik kennis gemaakt met den gouverneur dezer kolonie, den heer $\mathrm{Crol}^{2}$ ), en den procureur des Konings, mr. de Rouville ${ }^{3}$ ), voor welken laatste ik een brief had van mr. Scherer te Haarlem, thans - na 4 maanden -- overhandigd. Deze heer ontving mij op zijn kantoor zeer beleefd; hij verzocht mij aan zijn huis een nader bezoek te brengen.

Dinsdag 4. Ik ontmoette hier de heeren zeeofficieren Schotborg ${ }^{4}$ ) en Wissel s); de laatste is officier van administratie aan boord van het fregat ,Zeeland”.

Woensdag 5. De mail, die hier gemeenlijk den 2 den of 3den aankomt, is er nog niet.

Donderdag 6. Gistermiddag kwam de mail, mij brengende brieven van de heeren Smissaert en Spengler \& Co. maar niets van Haarlem.

1) Jan Felix Adriaan Eugen van Lansberge (1839-1883) was officier bij het Nederlandsch West-Indische leger, en destijds als 2de luitenant-adjudant van den gouverneur, zijn vader. Hij bracht het tot garnizoenscommandant in Curaçao.

2) Johannes Didericus Crol (1807-1870) werd in 1859 als gezaghebber van Sint Maarten benoemd tot gouverneur van Curaçao; hij bleef dit tot 1866. N.N.B.W. X, 224.

3) Mr. A. M. de Rouville (1813-1881) was advocaat te Brielle, sedert 1856 procureur des Konings in Curaçao, waar hij later (1866-1871) gouverneur was. N.N.B.W. X, 841 .

4) Waarschijnlijk is bedoeld de luitenant ter zee 1ste klasse Anton Schotborgh, commandant van de ,,Vesuvius”. Hij was op Curaçao geboren op 1 Juni 1821 als zoon van Hendrik en M. J. Kikkert. Einde $1862 \mathrm{nam}$ hij het bevel over de zeemacht in West-Indië, te voren door den nog te noemen kapitein ter zee Fabius gevoerd, op zich. Ook kan bedoeld zijn Henry Schotborgh (1841-1896), die als adelborst 1ste kl. aan boord Zr. Ms. „Cornelis Dirks” van Januari 1861 tot Aug. 1862 in West-Indië vertoefde.

s) F. W. Wissel was als officier van administratie 1ste kl. aan boord van Zr. Ms. ,ZZeeland”. Hij overleed aan dit boord 11 Mei 1862. 
Vrijdag 7. De binnenkomst der haven van Curaçao wordt verdedigd door een fort links en een fort rechts alsmede een fort, vlak tegenover de monding gelegen, hoewel ver daarvandaan, boven op een berg. De haven binnenkomende, heeft men de Willemstad rechts en de Overzijde links van de baai, die tot diep in 't eiland doorloopt. Deze beide stadsgedeelten zijn niet door bruggen met elkander vereenigd: het onderhoud der gemeenschap heeft plaats met ponten, welke voortgestuwd worden door een met een roeiriem voorzienen man. Dag en nacht zijn er altijd genoegzaam ponten om ieder over te zetten, wat telkens voor een of een paar heeren 5 centen kost.

Zaterdag 8 . Het Curaçaosche heldere weer schijnt zijn zetel wederom ingenomen te hebben, waardoor mij vergund wordt te wandelen. Hedenochtend was het naar Pietermaai, een voorstad beoosten de Willemstad, waar ik zeer schoone huizen en buitenplaatsen zag.

Zondag 9. Wandelde des morgens naar Schaarloo om den heer Abraham Jesurun te zijnen huize een bezoek te brengen, maar hij was naar zijn kantoor in de Willemstad en dus wandelde ik getroost huiswaarts.

Maandag Io bezocht ik in 't fort Amsterdam den heer J. H. Beaujon 1) op zijn kantoor, nadat ik bereids een dag of 8 te voren hem en zijne echtgenoote te hunnen huize een bezoek gebracht had. De heer Beaujon is niet gezond en sukkelt veel. Hij verzocht mij wel zijn groeten naar Nederland over te brengen. Het is hier alles klip en koraal, tot de huizen toe, waarvan de muren van gehouwen klipsteen en kalk gebouwd worden. Brand is hier een weinig gekend euvel, zelfs gaat men zoo ver van te zeggen, dat hier geen brand kan ontstaan. De vorige week bemerkte ik pijn aan mijn linkervoetzool; vóór een paar dagen vermeende ik, dat een kleine Surinaamsche gast - een zich tusschen het vel en vleesch der voetzool zich nestelende ,sika" - in mijn gezelschap de reis herwaarts had gedaan, zoodat ik gister het besluit nam met een speld de voetzool open te krabben en daarna gaf ik de wond en de sika, die ik niet wist te bemachtigen, een geregeld eaudecologne-bad. Den heeren De Rouville en Smeele 2) bracht ik

1) J. H. Beaujon was koloniaal secretaris, belast met de notarieele functiēn, schoolopziener en ouderling bij de Vereenigde protestantsche gemeente.

2) Mr. J. P. Smeele (1832-1888) was advocaat te 's-Gravenhage, toen hij in 1860 werd benoemd tot bezoldigd gegradueerd lid der rechtbank in Curaçao, later Hof van justitie. In 1872 werd hij voorzitter van dit college en in 1878 procureur-generaal. N.N.B.W. X, 938. 
in 't laatst der vorige week een bezoek te hunnen huize, en werd mede door hunne echtgenooten zeer wel ontvangen.

Dinsdag $I I$. De dag lieverde niets op, dan dat ik mij beter gevoelde.

Woensdag I2. Heden zag ik voor het eerst een man in de baai bezig met visschen. Het is zonderling, dat ik hier genoegzaam nog geen visch van eenig aanbelang zag.

Donderdag 13. Hedenmorgen vertrok uit de haven naar Coro, een plaats op de Venezuelaansche kust, Zuid van Curaçao, de Nederlandsche oorlogsstoomboot „Djambi” om de belangen der daar gevestigde Nederlanders te beschermen.

Vrijdag I4. Gisteravond heb ik een bezoek gebracht bij den heer Abraham Jesurun, wonende in zijn fraai huis „Marra Villa” te Schaarloo, waar ik voorgesteld werd aan mevrouw Esther Jesurun - die een heel lief 3-jarig dochtertje heeft - en verscheidene heeren, allen van de stam Israëls. Er werd kaart gespeeld; ik vond plaats met den gastheer, Dr. Henriques en den heer Haay Senior, aan een whistpartijtje. In den vooravond werd een delicieuze kop chocolade gepresenteerd en verder ging de avond als alle kaartpartijtjes om. Ik had veel genoegen en om 11 uur was ik thuis. Het passeeren van de baai bij helderen maneschijn was recht aangenaam op dat uur.

Zaterdag I5. Toen ik Donderdagavond ten huize van den heer Abraham Jesurun was, deelde ik hem mede, dat ik gaarne met zijn vader kennis zoude maken, en ik vernam toen, dat Zaterdag tusschen 9 en 10 uur stellig gelegenheid zou zijn om den ouden heer Jesurun in zijn woning aan de werf te ontmoeten. Alzoo ging ik hedenochtend derwaarts en vond den vader Jacob A. Jesurun met den zoon Abraham in gesprek. Ik werd met een vriendelijk woord door beiden ontvangen en genoodigd de scheepstimmerwerf en de daaraan verbonden magazijnen te zien. Ik trof het, dat een schoener van 20 ton afgetimmerd was en te water gelaten werd. De vader vertelde mij, dat hij eigenaar was van 400 slaven, waarvan het manlijk deel in verschillende ambachten bekwaam was en in de dagen der week een loon verdiende, echter heden, op den israëlietischen feestdag, loon ontvingen als vrije arbeiders, zoo zij begeerden te werken, hetgeen op andere dagen verplichtend was. Toen wij in huis kwamen, werd ik voorgesteld aan mevrouw Jesurun met wie ik een buiging wisselde daar ik geen Spaansch of Papiëmentsch spreek en zij mijne taalkennis niet bereikte. Ook met verscheidene dochters en schoondochters maakte ik kennis. Toen ik een kop koffie met een gebakje gebruikt had, 
meende ik afscheid te mogen nemen. Mis, de oude 55-jarige heer was er op gesteld, dat ik bleef ontbijten in den kring der zijnen en ik, die nimmer ten huize eens Israëliets gespijsd had, liet mij die uitnoodiging welgevallen. Met ons veertienen zaten wij aan den disch, waaronder 3 allerliefste jeugdige kleinkinderen van den ouden man. Ik zat ter rechterzijde van de gastvrouw met welke ik geen woord kon spreken, maar rechts van mij zat een zoon des huizes, die doctor in de medicijnen is van Göttingsche studie en Utrechtsche promotie, en bepaald belast was voor mij te zorgen. De disch was welvoorzien en de spijzen waren wel en smakelijk bereid. Toen wij na den maaltijd een kop koffie dronken, begon een van de heeren - wiens naam ik niet onthouden heb - een gesprek in 't Spaansch over het verschil tusschen protestanten en roomsch-katholieken, terwijl de andere heeren het gesprek met hem onderhielden en ik luisterde. Mijn sigaar ten einde zijnde, nam ik een gunstig oogenblik waar om mijn afscheid van het geacht israëlietisch gezelschap te nemen en vroeg den genoemden redenaar, of hij mij voor een roomsch-katholiek of een protestant hield? Met een beleefde buiging gat hij mij ten antwoord, dat hij mij voor een goed christen hield. Ik maakte hem mijn compliment voor zijn bescheiden antwoord, groette de dames en heeren en wandelde huiswaarts.

Zondag I6. Dominee Dissel 1) hoorde ik hedenmorgen in het Gereformeerde kerkgebouw een gezonde rede uitspreken naar aanleiding van Lucas 18, vers 9-14. De gemeente was vrij wel opgekomen in de gedaante van soldaten en matrozen, eenige officieren, waaronder 2 met dikke epauletten, en voorts eenige kakelbont getooide dames, waarvan eene in het kanariegeel gedoscht was; particulieren en ambtenaren waren vertegenwoordigd. Was ik in Paramaribo verwonderd over zoovele vrouwen met zwarte gezichten in inlandsche kleedij in het schip der kerk te zien, hier daarentegen was ik geneigd mijne bevreemding te slaken, dat het tropische element zoo goed als niet vertegenwoordigd was.

Maandag I7. Gisteravond was ik op receptie bij den gouverneur Crol, waar ik in kennis kwam met den kapitein-ter-zee Fabius 1),

1) Sybrand van Dissel (1806-1878) werd in 1856 predikant op Curaçao, hetgeen hij tot 1865 bleef; daarna was hij nog tot 1876 predikant te Paramaribo. N.N.B.W. VIII, 391.

2) Gerhardus Fabius (1806-1888) grondlegger der Japansche marine. Het stoomfregat ,,Zeeland” onder zijn bevel vertoefde van 26 September 1861 tot 12 September 1862 op Curaçao en in de omgeving daarvan. In ONZE VLOOT 1917 komt een beschrijving van deze reis van de ,Zeeland" voor. N.N.B.W. V, 187. 
voerende het fregat 1ste klasse met stoomvermogen ,Zeeland" en commandant van het eskader in deze wateren, voorts den kapitein-luitenant-ter-zee Hugenholtz ${ }^{1}$ ), mede aan boord van bedoelden bodem. Op een aangename wijze, ging de avond voor mij om, dan in gesprek met den een, dan in gesprek met iemand anders. Bij het scheiden verzocht de gouverneur mij in de week 's avonds aan te komen om te praten, daar hij en de familie elken avond thuis zijn.

Dinsdag I8. De dokter, wiens raad ik kort na mijn komst alhier inriep, laat mij meer en meer aan mijn lot over en dat is een goed sein. In deze plaats is het aangenaam, omdat het alles leven en bedrijf is. Elk drijft handel, al is 't in nog zoo'n klein lokaal; vrouwen en meisjes vlechten stroohoeden en sigarenkokers, terwijl de mannen schrijnwerkers, kleedermakers, schoenmakers, pontvoerders enz. zijn.

Woensdag I9. Heden, de verjaardag van onzen Koning, staan hier alle dagelijksche bezigheden stil. De menigte is opgewonden door 't feest van den dag en heeft alleen oor en oog voor de volksspelen, bestaande in hardroeierijen met velerhande soort van vaartuigen en sprietlooperijen in de Sint-Annabaai des voormiddags en andere spelen op den vasten wal des namiddags. Het koninklijk saluut doet muren en ramen trillen. Het verwondert mij, dat van het riffort geen vlag waait, en dat bij de volksspelen aan wal nevens de Nederlandsche vlag een Fransche vlag geplant is.

Donderdag 20. Gisteravond eindigde de pret met muziek, welke met te veel vaart afgespeeld werd, en vuurwerk, dat met te groote tusschenpoozen ontstoken werd. Hedenochtend bracht ik een bezoek bij den commandant van 't eskader Fabius en wandelde met Zijnhoogedelgestrenge op de kampanje van 't fregat ,Zeeland" op en neder, daar de krijgsraad in zijn zitvertrek vergaderd was.

Vrijdag 2 Februari I862. Gistermiddag kwam de mail en bracht voor mij niets, geen letter: zoo moet ik mij geruststellen met het spreekwoord ,,geene tijding, goede tijding". De laatste keeren had ik van de heeren Spengler \& Co. en Smissaert nog iets te lezen, maar nu niets. Morgen vertrekt de mail. Ik ben zoo wel als ik 't gansche jaar mij nog niet gevoelde. Als het eenigszins kan hoop ik in 't begin van April thuis te komen.

1) J. A. H. Hugenholtz (1825-1874). 